\title{
HUBUNGAN PENGETAHUAN REMAJA TENTANG MENSTRUASI DENGAN TINGKAT KECEMASAN DALAM MENGHADAPI MENARCHE PADA SISWI KELAS IV DAN V SDI DARUL HIKMAH KRIAN SIDOARJO
}

\author{
Widya Anggraeni' ${ }^{1}$ Kurnia Indriyanti Purnama Sari ${ }^{1}$ \\ ${ }^{1}$ STIKES Dian Husada Mojokerto \\ *Correspondence: \\ Widya Anggraeni \\ Email: widyainggit11@gmail.com
}

\begin{abstract}
Background: Menarche merupakan menstruasi pertama kali pada masa awal remaja. Dimasyarakat, masalah menstruasi masih dianggap tabu untuk dibicarakan, sehingga remaja awal kurang memiliki pengetahuan dan sikap yang cukup baik tentang perubahan fisik dan psikologis terkait menarche. Biasanya remaja putri mengalami kegelisahan, adanya rasa takut, kerisauan dan kecemasan ketika menghadapi menarche.

Purpose: Tujuan dari penelitian ini adalah untuk mengidentifikasi dan menganalisis hubungan pengetahuan remaja putri tentang menstruasi dengan tingkat kecemasan dalam menghadapi menarche.

Method: Desain penelitian ini adalah Analitik dengan metode Cross Sectional, populasi sebanyak 41 siswi kelas IV dan V yang belum dan sudah menstruasi di SDN Sadar Tengah Mojoanyar Sampel sebanyak 38 siswi dengan teknik purposive sampling. Data diambil dari 2 variabel yang ada, yaitu pengetahuan remaja tentang menstruasi, dan tingkat kecemasan dalam menghadapi menarche, dengan menggunakan kuesioner. Setelah ditabulasi, data yang ada dianalisis menggunakan uji statistic spearman Rho dengan tingkat kemaknaan $\alpha<0,05$.

Results: Dari hasil penelitian diperoleh data paling banyak responden bepengetahuan baik mengalami cemas ringan yaitu 17 siswi $(44,73 \%)$, berpengetahuan cukup mengalami cemas sedang sebanyak 8 siswi $(18,42 \%)$, dan yang berpengetahuan kurang mengalami cemas ringan sebanyak 3 siswi (7.89\%). Berdasarkan analisa data diketahui $\rho=0,009$ nilai signifikansi $\alpha=0,05$ yang artinya H1 diterima ada hubungan antara pengetahuan remaja putri tentang menstruasi dengan tingkat kecemasan dalam menghadapi menarche SDI Darul Hikmah Krian Sidoarjo.

Conclusion: Melihat hasil penelitian bahwa, semakin baik pengetahuannya maka semakin rendah tingkat kecemasannya, hal ini dipengaruhi oleh beberapa factor di antaranya pengetahuan, umur, perkembangan kepribadian. Hal ini perlu adanya informasi dan konseling tentang menarche untuk meminimalkan kecemasan.

Key words: Pengetahuan, Remaja, Menstruasi, Kecemasan, Menarche
\end{abstract}

\section{PENDAHULUAN}

Remaja adalah masa transisi dalam rentang kehidupan manusia, menghubungkan masa kanak- kanak dan masa dewasa. Mencakup perubahan biologis, kognitif dan sosio-emosional.
Perubahan yang sering kali diekspresikan sebagai peristiwa utama dalam kehidupan remaja putri adalah dimulainya menarche. (Santrock, 2003: 26). Menarche merupakan menstruasi pertama yang biasa terjadi dalam rentang usia 10-16 tahun atau pada 
masa awal remaja (Liewellyn, 2009: 1172). Selama ini sebagian besar masyarakat merasa tabu untuk membicarakan masalah menstruasi dalam keluarga, sehingga remaja awal kurang memiliki pengetahuan dan sikap yang cukup baik tentang perubahan - perubahan fisik dan psikologis terkait menarche. Menurut Kartono (2007: 216) seseorang mengaitkan adanya "Bahaya-bahaya atau kecelakaan" tertentu sehubungan dengan kotoran haid juga diidentifikasikan dengan darah yang najis dan haram, serta hal-hal yang sangat menjijikkan.

Berdasarkan hasil survey awal yang didapatkan dari data kependudukan di 2 RT

Desa Ngemplak kidul Kecamatan Margoyoso Kabupaten Pati, terdapat 378 jiwa penduduk dan terdapat $12 \%$ remaja putri (45 jiwa) yang berusia 11-14 tahun dari jumlah penduduk keseluruhan. Hasil study pendahuluan yang dilakukan dengan teknik wawancara pada 10 siswi kelas IV dan V SDI Darul Hikmah Krian Sidoarjo, diperoleh 6 siswi tidak tahu tentang menstruasi dan cemas dalam menghadapi menarche.

Gejala yang sering terjadi dan sangat mencolok pada peristiwa haid pertama ialah kecemasan atau ketakutan. Selain itu gejala patologis mungkin juga menyertai pada saat menstruasi mulai dari rasa pusing- pusing, rasa mual, amenorrhoe (terhentinya menstruasi), dysmenorrhoe (haid yang disertai rasa sakit dan rasa nyeri), haid yang tidak teratur, pendarahan terus menerus, vicarierende menstruatie (menstruasi pengganti), sampai gejala neurosa yang mengakibatkan terjadinya shock-reaction sehingga anak gadis melakukan usaha- usaha yang intensif untuk bunuh diri.
Pendidikan reproduksi remaja merupakan masalah penting yang perlu mendapatkan perhatian dari semua pihak, tidak hanya oleh petugas di institusi pelayanan kesehatan saja, namun juga orang tua, kerabat terdekat, guru, tokoh agama, serta masyarakat di lingkungan sekitarnya berperan dalam memberikan informasi sejak dini dan dukungan emosional. Pada remaja putri sangat penting sebagai bekal remaja putri dalam menghadapi menarche.

Tujuan umum penelitian ini adalah Untuk Mengetahui hubungan pengetahuan tentang menstruasi dengan kecemasan dalam menghadapi menarche pada siswi kelas IV Dan kelas V SDI Darul Hikmah Krian Sidoarjo.

\section{METODE DAN BAHAN}

Penelitian ini rancangan penelitian yang digunakan adalah teknik cross sectional yaitu peneliti melakukan observasi atau pengamatan variabel pada satu saat (point time approach). Sebagai populasi dalam penelitian ini adalah semua siswi kelas IV Dan kelas V SDI Darul Hikmah Krian Sidoarjo sebanyak 41 siswi. Teknik pengambilan sampel dalam penelitian ini adalah menggunakan purposive sampling yaitu pengambilan secara purposive didasarkan pada suatu pertimbangan tertentu yang dibuat oleh peneliti sendiri, berdasarkan ciri atau sifat sifat populasi sudah diketahui sebelumnya (Notoatmodjo, 2005: 88). Data yang diperoleh dianalisis dan disajikan dalam bentuk tabel frekuensi. 
HASIL PENELITIAN

Pengetahuan Remaja Putri Tentang Menstruasi.

Tabel 1. Pengetahuan Remaja Putri tentang Mentruasi di SDI Darul Hikmah Krian Sidoarjo.

\begin{tabular}{|c|c|c|c|}
\hline No. & Pengetahuan & Frekuensi & Prosentase \\
\hline 1. & Baik & 23 & $60,52 \%$ \\
\hline 2. & Cukup & 12 & $31,57 \%$ \\
\hline 3. & Kurang & 3 & $7,89 \%$ \\
\hline \multicolumn{2}{r}{ Total } & 38 & $100 \%$ \\
\hline
\end{tabular}

Berdasarkan tabel diatas menunjukkan bahwa pengetahuan remaja putri di SDI Darul Hikmah Krian Sidoarjo didapatkan sebagian besar memiliki pengetahuan baik tentang menstruasi yaitu sebanyak 23 responden $(60,52 \%)$.

\section{Kecemasan Remaja Putri Dalam Menghadapi Menarche.}

Tabel 2. Kecemasan Remaja Putri dalam menghadapi Menarche di SDI Darul Hikmah Krian Sidoarjo.

\begin{tabular}{|c|l|c|c|}
\hline No & \multicolumn{1}{|c|}{ Kecemasan } & Frekuensi & Prosentase \\
\hline 1. & Tidak Ada Kecemasan & 0 & $0 \%$ \\
\hline 2. & Kecemasan Ringan & 28 & $73,68 \%$ \\
\hline 3. & Kecemasan Sedang & 10 & $31,57 \%$ \\
\hline 4. & $\begin{array}{l}\text { Kecemasan } \\
\text { Berat/panik }\end{array}$ & 0 & $0 \%$ \\
\hline \multicolumn{2}{|c|}{ Total } & 38 & $100 \%$ \\
\hline
\end{tabular}

\section{Berdasarkan tabel diatas} menunjukkan bahwa tingkat kecemasan remaja putri dalam menghadapi menarche didapatkan sebagian besar responden mengalami kecemasan ringan yaitu 28 responden $(73,68 \%)$, dan sebagian kecil mengalami kecemasan sedang yaitu 10 responden $(31,57 \%)$ dalam menghadapi menarche.
Hubungan Pengetahuan Remaja Putri Tentang Menstruasi Dengan Tingkat Kecemasan Dalam Menghadapi Menarche Pada Siswi Kelas IV Dan V Di SDI Darul Hikmah Krian Sidoarjo.

Tabel 3. Tabulasi Silang untuk menentukan Hubungan Pengetahuan Remaja Putri Tentang Menstruasi Dengan Tingkat Kecemasan Dalam Menghadapi Menarche Pada Siswi Kelas IV Dan V Di SDI Darul Hikmah Krian Sidoarjo.

\begin{tabular}{|c|c|c|c|c|c|c|c|c|c|c|}
\hline \multirow{3}{*}{$\begin{array}{l}\text { Pengeta } \\
\text {-huan }\end{array}$} & \multicolumn{8}{|c|}{ Tingkat Kecemasan } & \multicolumn{2}{|c|}{ Total } \\
\hline & \multicolumn{2}{|c|}{$\begin{array}{c}\text { Tidak } \\
\text { ada } \\
\text { cemas }\end{array}$} & \multicolumn{2}{|c|}{$\begin{array}{l}\text { Cemas } \\
\text { ringan }\end{array}$} & \multicolumn{2}{|c|}{$\begin{array}{l}\text { Cemas } \\
\text { sedang }\end{array}$} & \multicolumn{2}{|c|}{$\begin{array}{c}\text { Cemas } \\
\text { berat/ } \\
\text { panik }\end{array}$} & & \\
\hline & $f$ & $\%$ & $\mathrm{~F}$ & $\%$ & $f$ & $\%$ & $f$ & $\%$ & $\mathrm{~F}$ & $\%$ \\
\hline Baik & 0 & 0 & 17 & 44,73 & 6 & 15,76 & 0 & 0 & 23 & 60,52 \\
\hline Cukup & 0 & 0 & 8 & 18,42 & 4 & 19,52 & 0 & 0 & 12 & 31,57 \\
\hline kurang & 0 & 0 & 3 & 7,89 & 0 & 0 & 0 & 0 & 3 & 7,89 \\
\hline Total & 0 & 0 & 28 & 26,06 & 10 & 26.31 & 0 & 0 & 38 & 100 \\
\hline
\end{tabular}

Berdasarkan tabulasi silang pada tabel diatas menunjukkan bahwa paling banyak responden berpengetahuan baik mengalami kecemasan ringan yaitu 17 responden $(44,73 \%)$, responden yang berpengetahuan cukup dan mengalami kecemasan sedang sebanyak 8 responden $(18,42 \%)$, dan responden berpengetahuan kurang dan mengalami kecemasan ringan sebanyak 3 responden (7.89\%). Dari hasil perhitungan dengan menggunakan uji Spearman Rank menunjukkan bahwa $\rho<\alpha$ dengan taraf kemaknaan $(\alpha=0,05)$. hasil perhitungan adalah $\rho=0,009$ kurang dari 0,05 maka $\mathrm{H} 1$ diterima artinya ada hubungan pengetahuan tentang menstruasi dengan kecemasan dalam menghadapi menarche pada siswi kelas IV Dan V Di SDI Darul Hikmah Krian Sidoarjo. 
PEMBAHASAN

Hubungan Pengetahuan Remaja Putri Tentang Menstruasi Dengan Tingkat Kecemasan Dalam Menghadapi Menarche Pada Siswi Kelas IV Dan V Di SDI Darul Hikmah Krian Sidoarjo.

Berdasarkan hasil penelitian didapatkan bahwa ada hubungan pengetahuan tentang menstruasi dengan kecemasan dalam menghadapi menarche pada siswi kelas IV Dan V Di SDI Darul Hikmah Krian Sidoarjo yang dapat dilihat dari hasil uji Spearmen Rank yang menunjukkan bahwa $\rho<\alpha$ dengan taraf kemaknaan $(\alpha=0,05)$, serta tabulasi silang yang menunjukkan bahwa paling banyak responden berpengetahuan baik mengalami kecemasan ringan yaitu 17 responden $(44,73 \%)$, responden yang berpengetahuan cukup dan mengalami kecemasan sedang sebanyak 8 responden $(18,42 \%)$, dan responden berpengetahuan kurang dan mengalami kecemasan ringan sebanyak 3 responden $(7.89 \%)$.

Hal tersebut menunjukkan bahwa semakin baik pengetahuan remaja putri tentang menstruasi, terutama pengenalan tanda-tanda awal mentruasi, akan menjadikan remaja putri tersebut memiliki tingkat kecemasan yang rendah. Hal tersebut dapat dikarenakan mereka tidak khawatir ketika gejala patologis awal mentruasi mulai muncul saat awal menstruasi, mulai dari rasa pusing-pusing, rasa mual, amenorrhoe (terhentinya menstruasi), dysmenorrhoe (haid yang disertai rasa sakit dan rasa nyeri), haid yang tidak teratur, pendarahan terus menerus, vicarierende menstruatie (menstruasi pengganti), sampai gejala neurosa yang mengakibatkan terjadinya shock-reaction sehingga anak gadis melakukan usahausaha yang intensif untuk bunuh diri.
Pendidikan reproduksi remaja merupakan masalah penting yang perlu mendapatkan perhatian dari semua pihak, tidak hanya oleh petugas di institusi pelayanan kesehatan saja, namun juga orang tua, kerabat terdekat, guru, tokoh agama, serta masyarakat di lingkungan sekitarnya berperan dalam memberikan informasi sejak dini dan dukungan emosional. Pada remaja putri sangat penting sebagai bekal remaja putri dalam menghadapi menarche.

\section{SIMPULAN}

1. Pengetahuan Siswi kelas IV dan V SDI Darul Hikmah Krian Sidoarjo tentang Menstruasi sebagian besar memiliki pengetahuan baik yaitu 24 responden $(63,15 \%)$.

2. Kecemasan siswi kelas IV dan V SDI Darul Hikmah Krian Sidoarjo dalam menghadapi menarche sebagian besar responden memiliki kecemasan ringan yaitu 26 responden $(64,42 \%)$.

3. Siswi yang berpengetahuan baik dan memiliki tingkat kecemasan ringan sebanyak 17 responden $(44,73 \%)$.

4. Hasil uji statistik dengan uji Spearman Rank menunjukkan bahwa $\rho<\alpha$ dengan taraf signifikansi $(\alpha=0,05)$ maka Ho ditolak dan $\mathrm{H} 1$ diterima sehingga dapat dikatakan ada hubungan pengetahuan tentang menstruasi dengan tingkat kecemasan dalam menghadapi menarche.

\section{SARAN}

1. Bagi instansi kesehatan diharapkan dengan adanya hasil penelitian ini mampu menciptakan lulusan tenaga kesehatan yang berkualitas baik dan mampu untuk memberikan pendidikan kesehatan kepada masyarakat, terutama 
mengenai kesehatan reproduksi remaja sehingga dapat mengurangi tingkat kecemasan remaja putri dalam menghadi menarche.

2. Bagi responden, menstruasi merupakan suatu proses alamiah yang akan dialami olehsemua perempuan yang tidak dapat dihindari maka diharapkan responden lebih banyak membaca/ mencari informasi tentang sesuatu yang berhubungan dengan menstruasi untuk mengurangi tingkat kecemasan yang dialaminya.

3. Bagi peneliti dan peneliti selanjutnya, Mengingat adanya keterbatasan dalam penelitian ini, maka peneliti sangat mengharap bagi peneliti selanjutnya diharapkan mampu melanjutkan penelitian dengan meningkatkan jumlah sampel maupun menyempurnakan instrumen data yang digunakan.

\section{DAFTAR PUSTAKA}

1. Arikunto, S. (2006). Prosedur Penelitian Suatu Pendekatan. Jakarta: Rineka Cipta.

2. Babag, Lowdermik, Jansen. (2004). Buku Ajar Keperawatan Maternitas. Jakarta: EGC.

3. Liewellyn, D. (2001). Dasar-Dasar Obstretri Dan Ginekologi Jakarta: Rineka Cipta.

4. Liewellyn, D. (2009). Setiap Wanita. Jakarta: Delapratasa Publishing.

5. Efendi, F. (2007). Koping Adapati Menarche Sebagai Strategi Peningkatan Kesehatan Reproduksi Remaja. (Http://Ferry efendi.Blogspot.Com. Diakses 2 November 2009)
6. Hidayat, A. Aziz. (2003). Riset Keperawatan Dan Teknik Penulisan Ilmiah. Jakarta: Salemba Medika.

7. Kartono, K. (2007). Psikologi Anak Psikologi Perkembangan. Bandung: CV. Mandar Maju.

8. Manuaba, I.B.G. (1999). Memahami Kesehatan Reproduksi Wanita. Jakarta: Arcan.

9. Nike. (2008). Menarche Pada Remaja Putri.

(Http://Sustercantik.Blogspot.Com, Diakses 2 Nopember 2009).

10. Notoatmodjo, S. (2003). Ilmu Kesehatan Masyarakat: PrinsipPrinsip Dasar. Jakarta: Rineka Cipta.

11. Notoatmodjo, Soekidjo. (2005). Metodologi Penelitian Kesehatan. Jakarta: Rineka Cipta.

12. Notoatmodjo, Soekidjo. (2007). Pengantar Pendidikan Kesehatan Dan Ilmu Perilaku Kesehatan. Jakarta: Rineka Cipta.

13. Nursalam. (2003). Konsep Dan Penerapan Metodologi Penelitian Ilmu Keperawatan Pedoman Skripsi, Tesis Dan Instrument Peneltiian Keperawatan. Jakarta: Salemba Medika.

14. Nursalam. (2008). Konsep Dan Penerapan Metodologi Penelitian Ilmu Keperawatan: Pedoman Skripsi, Tesis Dan Instrument Peneletian Keperawatan. Jakarta: Salemba Medika .

15. PrawiroHardjo, Sarwono. (2005). Ilmu Kandungan. Jakarta: Yayasan Bina Pustaka.

16. PrawiroHardjo, Sarwono. (2005). Ilmu Kandungan. Jakarta: Yayasan Bina Pustaka.

17. Price Anderson Sylvia, Wilson Mc Carti Lorraine. (1995). Patofisiologi 
konsep klinis proses-proses penyakit. Jakarta: EGC.

18. Robert, P. (2000). Apa yang ingin diketahui remaja tentang sex. Jakarta: Bumi Aksara.

19. Santrock, J.W. (2003). Adolescense perkembangan remaja. Jakarta: Erlangga.

20. Sherwood, Laurale. (2001). Fisiologi manusia. Jakarta : EGC.

21. Soetjiningsih.(2004).

Tumbuh

Kembang Remaja Dan

Permasalahannya. Jakarta: Sagung Seto.

22. Stuart, Gail, W. (2002). Buku Saku Keperawatan Jiwa. Jakarta: EGC.

23. Suzame. C. Smeltzer. (2002). Buku Ajar Keperawatan Medical Bedah. Jakarta: EGC.

Cite This Article As: Anggraeni, W., Sari, K.I.P. Hubungan Pengetahuan Remaja Tentang Menstruasi Dengan Tingkat Kecemasan Dalam Menghadapi Menarche Pada Siswi Kelas IV Dan V SDI Darul Hikmah Krian Sidoarjo. Nurse and Health: Jurnal Keperawatan 2018; 7(1): $80-85$. 